\title{
IAMJ
}

INTERNATIONAL

AYURVEDIC

MEDICAL JOURNAL

ISSN: 2320-5091

Impact Factor: 6.719

\section{AN OPEN CLINICAL STUDY TO ASSESS THE COMBINED EFFECT OF JANUBASTHI AND MATRA BASTHI WITH SAIREYAKA TAILA IN JANUSANDHIGATAVATA W.S.R TO OSTEOARTHRITIS OF KNEE JOINT}

\author{
Diksha Masimade ${ }^{1}$, Rajesh Sugur ${ }^{2}$, Doddabasayya ${ }^{3}$ \\ PG Scholar, Guide, Coguide and HOD \\ Department of Panchakarma, TGAMC, Bellary, Karnataka, India
}

Corresponding Author: dmasimade@gmail.com

https://doi.org/10.46607/iamj0709112021

(Published Online: November 2021)

Open Access

(C) International Ayurvedic Medical Journal, India

Article Received: 17/10//2021 - Peer Reviewed: 30/10/2021 - Accepted for Publication: 31/10/2021

\section{Check for updates}

\begin{abstract}
Basti is considered the best modality of treatment in managing the disorders of Vata Dosha. As Sandhigatavata is also one among Vatavyadhi, Basti is the effective line of treatment, which is characterized by swelling, pain during flexion and extension of joints. Osteoarthritis is a common degenerative joint condition with a prevalence of about $22 \%$ to $39 \%$ in India. There is a steady rise in prevalence from age 30 such that by age $65,80 \%$ of people will have radiographic evidence of osteoarthritis. It is caused by the degradation of the joints, the articular cartilages and subchondral bone. It is characterized by pain, stiffness and loss of flexibility of joints. ${ }^{1}$ By foregoing, Sandhigatavata can be readily correlated to Osteoarthritis. In contemporary medical science, they use NSAIDs for control of the symptoms. Acharya Sushrutha and Acharya Charaka have mentioned Snehana (Oleation) as a line of treatment in Sandhigatavata. So here an attempt is made through Janubasthi and Matrabasthi using Saireyaka Taila ${ }^{2}$ mentioned in Gada Nigraha under Vata Vyadhi for treating Janusandhigatavata in specific. Method: This study is an open-label, observational and clinical study containing 30 patients, who were posted for Janu Basti and Matra Basti with Saireyaka Taila for 9 days. The assessment was carried out before treatment, during treatment $\left(5^{\text {th }}\right.$ day), after treatment (on $10^{\text {th }}$ day) and after following up ( $28^{\text {th }}$ day) and the gradings were noted. Results: Out of 30 patients in this study, 5 patients (17\%) were getting Moderate Improvement and 25 patients (83\%) were getting
\end{abstract}


Good Improvement. The overall effect of the treatment is $69.44 \%$. Conclusion: It is concluded that the combined effect of Janubasti and Matrabasti with Saireyaka Taila is clinically and statistically significant in almost all the parameters.

Keywords: Janu Basti, Matra Basti, Sandhivata, Osteoarthritis, Saireyaka Taila.

\section{INTRODUCTION}

Ayurveda, the all-time medicine has been showering its valuable treasures to mankind since time unknown. Still the same is continuing with more and more global support. Since this medical science treats the patient, it differs and occupies its special place than other medical branches which give attention only to the presenting signs and symptoms of the patient.

'PANCHAKARMA' means the five therapeutic techniques of the unique speciality of Ayurveda viz., $V a$ mana, Virechana, Asthapana Basti, Anuvasana Basti and Nasya. Basti is considered as Ardha Chikitsa (half of the whole treatments) by Acharya Charaka.

Disease Sandhigatavata can be defined as a disease of Sandhi (Joint) with symptoms of Sandhishula, Sandhishotha and Akunchana Prasarana Pravritti Savedana and in the later stage Hanti Sandhigatah. Osteoarthritis can be considered as Sandhivata. In Ayurveda, Acharya Charaka was the first person to describe the disease separately named "Sandhigata Anila" under the heading of Vatavyadhi. Acharya Vagbhata has considered Vatavyadhi as Maharoga. To date, Sandhivata is a challenging disease and is the important cause of disability in industrialized countries. Sandhivata is a disease occurring because of the affliction of Sandhis by vitiated Vata Dosha. The development of this disease is attributed to Vata Dosha Vriddhi due to age-related Dhatu Kshaya. Vatika Ahara Vihara predominance results in Sleshaka Kapha Kshaya in Sandhis because of Khavaigunya in Asthivaha and Majjavaha Srotas. Sandhis are one of the types of Marmas and are an integral part of Madhyama Roga Marga. Thus, the involvement of Marma, Madhyamarogamarga, Vatadosha and Dhatukshaya make disease Kasthasadhya.

The condition is much similar to osteoarthritis, a degenerative joint disease in its modern counterpart. Osteoarthritis or degenerative arthritis is a degenerative joint disorder characterized by degeneration of joint cartilage and adjacent bone that can cause joint pain and stiffness. This is the most common of all joint disorders that affect men and women in equal ratios. The prevalence of this diarthrodial (synovial lined movable) joint disease is estimated to be $1-2 \%$ worldwide. Since OA is the most commonly disturbing joint disease several analgesics and anti-inflammatory drugs are available to it. However, permanent relief is not provided by any of these and the same is still under research works that to be provided to this clinical mystery.

Acharya Sushrutha and Acharya Charaka have mentioned Snehana (Bahya, Abhyantara) and Swedana ${ }^{(3,4)}$ as a line of treatment in Sandhigatavata. Basthi plays a major role in mitigating vitiated Vata Dosha and thus relieves the pain in Sandhigatavata.

Knees are the weight-bearing joints where wear and tear type of degenerative arthritis occur most often which hampers the day-to-day activities. So here an attempt is made through Janubasthi and Matrabasthi using Saireyaka Taila mentioned in Gada Nigraha under Vata Vyadhi for treating Janusandhigatavata.

\section{MATERIALS AND METHODS}

\section{A. Sample Source:}

Patients suffering from Janusandhigatavata were selected from the OPD and IPD of Taranath Government Ayurvedic Hospital Ballari.

B. Drug Source: Preparation of Saireyaka Taila: • Tila Taila - 1part - Saireyaka Kwatha -4 parts • Saireyaka Kalka-1/4th part $•$ Paya- equal to Tila Taila

\section{Diagnostic criteria:}

Individuals were selected as per the classical Lakshanas(symptoms) of Sandhigata Vata and based on signs and symptoms of osteoarthritis of contemporary science. 


\section{Inclusion Criteria:}

1. Patients have classical signs and symptoms of $\mathrm{Ja}$ nusandhigatavata like Shoola, Shotha and Prasarana Akunchanoyar Pravruttischa Vedana.

2. Age between 30 to 70 years of either sex.

3. Patients fit for Matrabasthi

\section{Exclusion Criteria:}

1. Patients with Vatarakta, Amavata, Koshtukashirsha, Rheumatoid arthritis, gouty arthritis, psoriatic arthritis and other diseases of knee joints.

2. Patients with other systemic diseases interfere with the treatment.

3. Patients having traumatic, neoplastic, and infectious conditions of knee joints.

\section{STUDY DESIGN}

An open-label clinical study

\section{Sample Size:}

A minimum of 30 patients fulfilling the inclusion criteria was selected.

\section{Materials required for the study:}

For JanuBasti: Gas stove, lighter, cylinder, vessels, cotton, Masha Pishti (flour of black gram), hot water, goniometer and Saireyaka Taila.

For Matra Basti: Gas stove, cylinder, lighter, vessels, rubber catheter, enema syringe, Saireyaka Taila, Shatapushpa Churna, Saindhava Lavana, Latex hand gloves, Droni, Khalwa Yantra, measuring jar, Peshani and cotton swabs.

Methodology of the study: The patients who fulfilled inclusion criteria were examined for both subjective and objective parameters using the VAS scale and goniometer, the gradings noted. And then informed consent was taken before the treatment.

\section{Method of Janu Basti:}

Purvakarma: The patient is made to sit with legs extended and both knees exposed. Saireyaka Taila is taken in a vessel and heated indirectly, Masha Pishti rings are made which later is applied over Janu making a pit of about 4 Angula, with help of hot water it is sealed well so that it does not leak.

Pradhana Karma: Indirectly heated Saireyaka Taila with the help of cotton gauze is poured in a circular motion and uniform pressure. The temperature is checked for the patient's tolerability and temperature is maintained throughout the procedure for 45 minutes by changing it after it cools down.

Paschat Karma: Taila removed with cotton gauze, Masha Pishti is removed, and circular massage is done over bilateral knee joints. Advised patient to keep the Masha Pishti in Fridge for further use.

\section{Method of administration of Matra Basti:}

Purvakarma: The $72 \mathrm{ml}$ of Saireyaka Taila is taken in a measuring jar, later processed with Shatapushpa Churna and Saindhava Lavana in Khalva Yantra, and made lukewarm by indirect heat and loaded in enema syringe, to its mouth rubber catheter is connected and smeared with the Sneha at point of entry.

The patient is made to lie on Droni in the left lateral position with right knee flexed and asked to unclothe and Gudabhaga is examined for any fissures or pile mass, later Guda is smeared with Sneha.

\section{Pradhana Karma:}

The patient is asked to breathe through the mouth and slowly the rubber catheter is inserted in Guda, later the Sneha is pushed uniformly, care is taken to remove the air bubbles and the last $5 \mathrm{ml}$ of the Sneha should be retained to prevent the entry of air in Guda.

Paschat Karma: The catheter is removed slowly, patting over the buttocks is done and the patient is asked to raise the legs thrice and the patient is asked to lie down in a supine position for 15 minutes.

The time of administration and expulsion of Basti Dravya, Samyak Anuvasita Lakshanas and any complications noted daily.

Assessment is done DT- $5^{\text {th }}$ day, AT- On10th day and later gap of 18 days given and final assessment i.e AF.

\section{Assessment Criteria:}

\section{Subjective Criteria:}

- Janu Sandhi Shoola

- Pain-Visual Analogue Scale

- Stambha(stiffness)

Objective Criteria:

- JanuSandhi Shotha

- Janu Sandhi Sphutana

- Vedana during Prasarana and Akunchana of Janu Sandhi

- $\quad$ Range of motion -measured using Gonio meter 
Table 1: Intervention and Followup period:

\begin{tabular}{|c|c|c|c|c|}
\hline Type of treatment & Duration & Duration time of the procedure & Observation Period & Total study duration \\
\hline 1. Janubasthi & \multirow[b]{2}{*}{ 9days } & 45minutes & \multirow{2}{*}{$\begin{array}{l}\text { DT- } 5^{\text {th }} \text { day } \\
\text { AT- } 10^{\text {th }} \text { day AF- } 18^{\text {th }} \text { day }\end{array}$} & \multirow[b]{2}{*}{ 28days } \\
\hline 2. Matrabasthi & & & & \\
\hline
\end{tabular}

Janubasthi is done to both the knee joints even if pathology lies in a single joint as a preventive measure.

Total No Patients enrolled 32
Excluded-2

No. of patients completed the course of treatment-30

\section{RESULTS}

Table 2: Effect of Janusandhishoola in Janusandhigatavata

\begin{tabular}{|c|c|c|c|c|c|c|c|c|c|}
\hline \multirow[t]{2}{*}{ Symptom } & & \multicolumn{2}{|c|}{ Measures } & & \multirow[t]{2}{*}{$\%$} & \multirow[t]{2}{*}{ S.D (+.) } & \multirow[t]{2}{*}{ S.E (+-) } & \multirow[t]{2}{*}{ t value } & \multirow[t]{2}{*}{ p value } \\
\hline & BT & & & & & & & & \\
\hline \multirow[t]{3}{*}{ Janusandhishoola } & \multirow[t]{3}{*}{5.07} & DT & 3.27 & 1.80 & 35.53 & 1.215 & 0.226 & 5.37 & $<0.05$ \\
\hline & & AT & 1.80 & 3.27 & 64.47 & 1.437 & 0.267 & 11.30 & $<0.05$ \\
\hline & & $\mathrm{AF}$ & 1.67 & 3.40 & 67.11 & 1.499 & 0.278 & 11.32 & $<0.05$ \\
\hline
\end{tabular}

Table 3: Effect of JanusandhiShotha in Janusandhigatavata

\begin{tabular}{|c|c|c|c|c|c|c|c|c|c|}
\hline \multirow[t]{2}{*}{ Symptom } & & \multicolumn{2}{|c|}{ Measures } & & \multirow[t]{2}{*}{$\%$} & \multirow{2}{*}{$\begin{array}{l}\text { S.D } \\
(+.)\end{array}$} & \multirow[t]{2}{*}{ S.E (+.) } & \multirow{2}{*}{$\begin{array}{l}\text { t } \\
\text { value }\end{array}$} & \multirow{2}{*}{$\begin{array}{l}p \\
\text { value }\end{array}$} \\
\hline & BT & & & & & & & & \\
\hline \multirow{3}{*}{$\begin{array}{l}\text { Janusandhi } \\
\text { Shotha }\end{array}$} & \multirow[t]{3}{*}{0.33} & DT & 0.27 & 0.07 & 20.00 & 0.365 & 0.068 & 0.29 & $>0.05$ \\
\hline & & AT & 0.20 & 0.13 & 40.00 & 0.507 & 0.094 & 0.66 & $>0.05$ \\
\hline & & $\mathrm{AF}$ & 0.00 & 0.33 & 100.00 & 0.922 & 0.171 & 1.98 & $<0.05$ \\
\hline
\end{tabular}

Table 4: Effect of Pain during flexion and extension in Janusandhigatavata

\begin{tabular}{|c|c|c|c|c|c|c|c|c|c|}
\hline Symptom & BT & \multicolumn{2}{|c|}{ Measures } & & $\%$ & $\begin{array}{l}\text { S.D } \\
(+-)\end{array}$ & S.E (+.) & t & $\begin{array}{l}\mathbf{p} \\
\text { value }\end{array}$ \\
\hline \multirow{3}{*}{$\begin{array}{l}\text { Pain during flex- } \\
\text { ion and extension }\end{array}$} & \multirow{3}{*}{2.33} & DT & 087 & 147 & 6286 & 1279 & 0238 & 466 & $<005$ \\
\hline & & AT & 0.27 & 2.07 & 88.57 & 1.337 & 0.248 & 7.71 & $<0.05$ \\
\hline & & $\mathrm{AF}$ & 0.27 & 2.07 & 88.57 & 1.230 & 0.228 & 7.71 & $<0.05$ \\
\hline
\end{tabular}

Table 5: Effect of Stambha in Janusandhigatavata

\begin{tabular}{|c|c|c|c|c|c|c|c|c|c|}
\hline Symptom & & Me & & & $\%$ & S.D & S.E & & \\
\hline Stambha & 093 & DT & 013 & 080 & 8571 & 0997 & 0185 & 386 & $<005$ \\
\hline Neambon & & AT & 0.00 & 0.93 & 100.00 & 1.015 & 0.188 & 5.04 & $<0.05$ \\
\hline & & $\mathrm{AF}$ & 0.00 & 0.93 & 100.00 & 1.015 & 0.188 & 5.04 & $<0.05$ \\
\hline
\end{tabular}

Table 6: Effect of Sandhi Sputana in Janusandhigatavata

\begin{tabular}{|c|c|c|c|c|c|c|c|c|c|}
\hline \multirow[t]{2}{*}{ Symptom } & & \multicolumn{2}{|c|}{ Measures } & & \multirow[t]{2}{*}{$\%$} & \multirow{2}{*}{$\begin{array}{l}\text { S.D } \\
(+.)\end{array}$} & \multirow{2}{*}{$\begin{array}{l}\text { S.E } \\
(+.)\end{array}$} & \multirow{2}{*}{$\begin{array}{l}\text { t } \\
\text { value }\end{array}$} & \multirow{2}{*}{$\begin{array}{l}p \\
\text { value }\end{array}$} \\
\hline & BT & & & & & & & & \\
\hline \multirow[t]{3}{*}{ Sandhi Sputana } & \multirow[t]{3}{*}{5.20} & DT & 4.33 & 0.87 & 16.67 & 1.008 & 0.187 & 2.77 & $<0.05$ \\
\hline & & AT & 3.27 & 1.93 & 37.18 & 1.112 & 0.207 & 7.09 & $<0.05$ \\
\hline & & $\mathrm{AF}$ & 2.80 & 2.40 & 46.15 & 1.102 & 0.205 & 9.33 & $<0.05$ \\
\hline
\end{tabular}


Table 7: Effect of Range of Motion in Janusandhigatavata

\begin{tabular}{|c|c|c|c|c|c|c|c|c|c|}
\hline \multirow[t]{2}{*}{ Symptom } & \multicolumn{2}{|c|}{ Measures } & & & \multirow[t]{2}{*}{$\%$} & \multirow{2}{*}{$\begin{array}{l}\text { S.D } \\
(+.)\end{array}$} & \multirow{2}{*}{$\begin{array}{l}\text { S.E } \\
(+.)\end{array}$} & \multirow{2}{*}{$\begin{array}{l}\mathbf{t} \\
\text { value }\end{array}$} & \multirow{2}{*}{$\begin{array}{l}\mathbf{p} \\
\text { value }\end{array}$} \\
\hline & BT & & & & & & & & \\
\hline \multirow{3}{*}{$\begin{array}{l}\text { Range of } \\
\text { Motion }\end{array}$} & \multirow[t]{3}{*}{5.00} & DT & 3.47 & 1.53 & 30.67 & 1.137 & 0.211 & 3.70 & $<0.05$ \\
\hline & & AT & 1.80 & 3.20 & 64.00 & 1.540 & 0.286 & 8.32 & $<0.05$ \\
\hline & & $\mathrm{AF}$ & 1.53 & 3.47 & 69.33 & 1.655 & 0.307 & 9.20 & $<0.05$ \\
\hline
\end{tabular}

Table 8: Effect of VAS Scale in Janusandhigatavata

\begin{tabular}{|c|c|c|c|c|c|c|c|c|c|}
\hline \multirow[t]{2}{*}{ Symptom } & \multicolumn{2}{|c|}{ Measures } & & & \multirow[t]{2}{*}{$\%$} & \multirow{2}{*}{$\begin{array}{l}\text { S.D } \\
(+.)\end{array}$} & \multirow{2}{*}{$\begin{array}{l}\text { S.E } \\
(+.)\end{array}$} & \multirow{2}{*}{$\begin{array}{l}\text { t } \\
\text { value }\end{array}$} & \multirow{2}{*}{$\begin{array}{l}p \\
\text { value }\end{array}$} \\
\hline & BT & & & & & & & & \\
\hline \multirow[t]{3}{*}{ VAS Scale } & \multirow[t]{3}{*}{8.10} & DT & 5.13 & 2.97 & 36.63 & 1.497 & 0.278 & 8.49 & $<0.05$ \\
\hline & & AT & 2.40 & 5.70 & 70.37 & 1.208 & 0.224 & 18.35 & $<0.05$ \\
\hline & & $\mathrm{AF}$ & 2.17 & 5.93 & 73.25 & 1.363 & 0.253 & 18.56 & $<0.05$ \\
\hline
\end{tabular}

Table 9: Overall effect of treatment

\section{Overall Effect of Treatment}

\begin{tabular}{|l|l|l|}
\hline Grading & Relief in Percentage & Relief in Patients \\
\hline Mild Improvement & $<26 \%$ & 0 \\
\hline Moderate Improvement & $26-50 \%$ & 5 \\
\hline Good Improvement & $>51 \%$ & 25 \\
\hline
\end{tabular}

In the Overall effect of treatment in Janusandhi(17\%) were getting Moderate Improvement and 25 pagatavata, out of 30 patients in this study, 5 patients tients $(83 \%)$ were getting Good Improvement. The overall effect of the treatment is $69.44 \%$

Graph 1: Showing overall effect of treatment

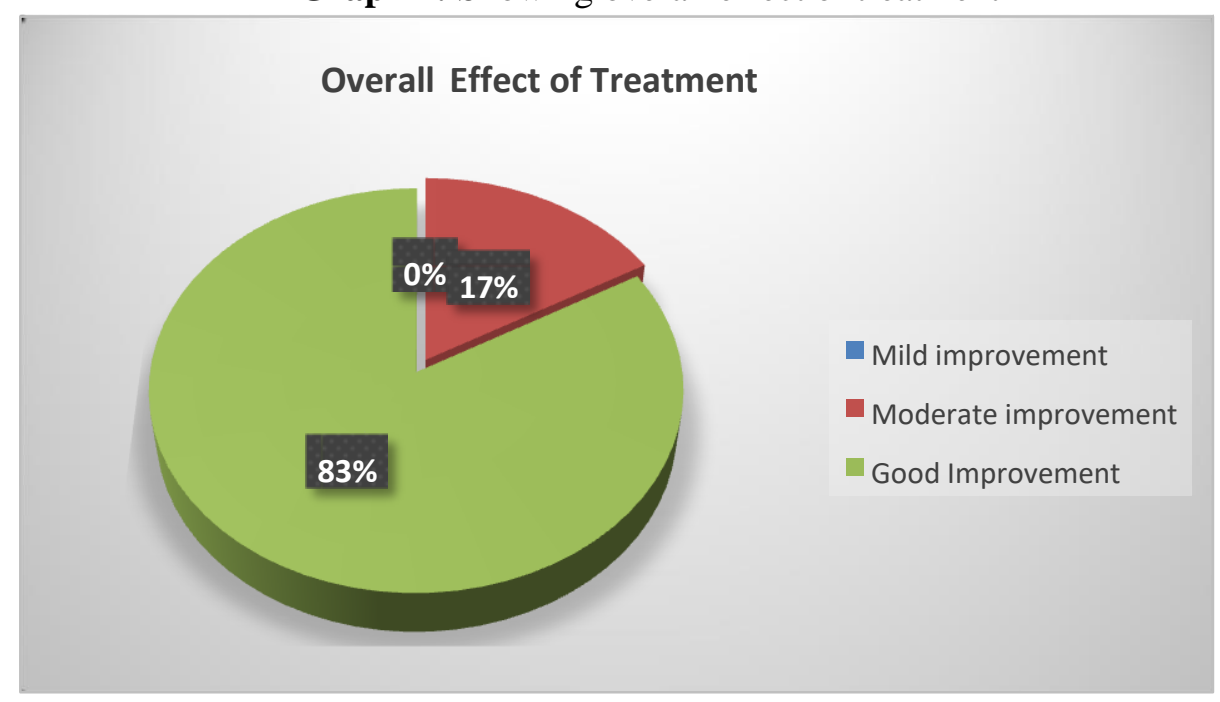




\section{DISCUSSION}

Sandhigata Vata is a disease in which the Prakupita Vata Dosha makes Sthana Samshraya at Sandhi \& make it unfit to perform its functions or to do the same with associated discomforts. While taking into consideration the Lakshanas of Sandhigata Vata, which are explained in Ayurvedic classics, we can compare it with the degenerative joint disease (Osteo Arthritis). O.A. is a condition that is associated with swelling, pain \& stiffness at the joints. Sandhigata Vata is described under Vata Vyadhi Chikitsita. In this Roga, Sandhi gets Vata Purna Druti Sparshata, Shopha \& painful movement.

Here the process of Samprapti initiation is due to the strong involvement of Nidana factors such as Vardhakya Avastha, Ativyayama. In Vardhakya (Old age) Vata Dosha dominates in the body. This in turn will cause Kapha Kshaya. As the Shleshma Bhava decreases in the body, Shleshaka Kapha in the joints gets a decrease in both quality and quantity. Reductions of Kapha in Sandhis make Sandhi Bandha Shithilata. Vatavrudhi leads to Asthidhatu Kshaya. Asthi being the main tissue of the joint, its Kshaya leads Khavaigunya in the joints. In the meantime, Sthanasamshraya of Prakupita Vata takes place in the Khavaigunyayukta Sandhi. This localized Vayu due to its Ruksha, Laghu Guna decreases the properties of Sleshaka Kapha producing disease Sandhi-Gata-Vata. The treatments of Sandhigatavata include Snehana, Upanaha, Agnikarma, Bandhana, And Unmardhana. Since it is a Vata Vikara and Dhatukshaya Janya Vikara, Snehana and Swedana are an ideal line of treatment. Acharya Charaka Mentioned repeated use of Snehana and Swedana.

Both Matra Basti and Janu basti were selected for mitigating Vata Dosha It was administered for 9 days. It was framed by considering the opinion of Acharya Sushruta that, Snehabasti administered for 9days reaches up to Majja Dhatu. Janusandhigatavata is a condition involving Asthi Dhatu and the Srotas involved is Asthivahasrotas So based on Acharya Sushruta's opinion Matrabasti was administered for 9 days ${ }^{5}$.
As Acharya Sushruta says, there will not be an occurrence of Shoola without Vata, the Saireyaka having the Vedana Sthapana ${ }^{6}$ property, and it does Vatahara action due to Ushna Veerya. and Taila having Snigdha, Guru Guna helps in Vatahara and increasing Shleshaka Kapha, leading to Shamana of Janusandhi Shoola

The creipatations occur mainly due to Vata Vruddhi and Shleshaka Kapha Kshaya, and Saireyaka Taila due to its Guru, Snighdha, Ushna Veerya and having Tikta Rasa and during the preparation it will be processed with Ksheera, thus helps in Asthi Poshana, improves the lubrication of synovial fluid and helps in reducing crepitations. And by this, there will be unrestricted joint movements.

Tikta Rasa dravyas have Jwaraghna and Daha Prashamana properties that Saireyaka may act as an anti-inflammatory agent and can reduce the pain and swelling of the joints. Taila is having Snigdha, Guru, Ushna and Bruhmana Gunas. Ksheera is said to have Bruhmana action and Vatahara Thus helps in the Samprapti Vighatana of the Janusandhigata Vata.

Taila was taken as it is chief Vata alleviating. $\mathbf{N a}$ Taila Dannat Param Asti Kinchith Dravyam Sameeranaarte. $^{7}$

Teshaam Tu Taila Vasa Majja Sarpishaam Yatha Purvam Sreshtam Vatashleshma Vikareshu Anuvasaneeyeshu, Yatha Uttaram Tu Pittavikare, Among Chatusneha, Taila is Shreshta for Vata Kaphaja disorders followed by Vasa, Majja and Ghrita in order, whereas for Pittaja disorders Ghrita, Majja, Vasa, Taila . ${ }^{8}$

Snehane Roukshyam Laghutaam Gurutvat Oushynyaat Cha Shaityam Pavanasya Hatva.Tailas inherent properties like Sneha entangles Ruksha Guna of Vata, Guru Guna - Laghu, Ushna Guna- Sheeta respectively thus alleviating morbid Vata Dosha.

And it gives immediate strength due to its Anu and Sukshma Guna and Pushti as mentioned by Kashyapa, which is required in all Dhatukshayaja disorders. Ruksha Guna plays a vital role in producing vitiation of Vata, which can be tackled by Snehaguna due to their opposite nature. Matra Basthi being a type of Snehabasthi plays a major role in management of 
Sandhigatavata. Basti enters the Pakvashaya which is the main Sthana of Vata Dosha and destroys Vata Dosha which is the originator of all Vikaras. By subsiding the Vata, all Vikara located in the other parts of the body also become allayed just as by the eradication of the roots of a plant, the stem, branches, sprouts, fruits, leaves etc, also vanish.

Janu Basthi is a kind of Snehayukta Sweda, Sagni, Ekanga, Snigdha, Madhyama, Drava, Samshamaniya type of Bahirparimarjana Chikitsa. Taila does Snehana there by Vatahara and due to Ushnata, Swedana also takes place. The Tiryak Dhamanis are connected to the Romakoopa, through these Dhamanis the Veerya of Aushadha are used in Abhaynga, Parisheka, Avagaha, Upanaha, Alepa enters the Twak and undergoes Paka through Bhrajaka Pitta. Acharya Vaghhata explains the same that Bhrajaka Pitta does the Pachana of drugs used for the Abhyanga, Parisheka and Lepa. In another context, it is said that oil used for anointing cleanses the channels of Sira, Roomakoopa and Dhamani and bestows strength to the body. Acharya Sushruta while explaining the benefits of Lepa, opines that the Veerya of Lepa Dravya enters the Romakoopa and is carried by Swedavaha Srotas. All these references in Samhita indicate the absorption of drugs applied over the skin.

SaireyakaTaila is mentioned in Gada Nigraha under Vata Vyadhi Chikitsa. It contains Saireyaka as its only ingredient. Saireyaka is Tikta Rasa Pradhana and as it will be processed with milk helps in Asthiposhana

\section{'BastayaKsheera Sarpishitiktopahatani Cha'?}

\section{CONCLUSION:}

This study is mainly taken to evaluate the combined effect of Janu Basti and Matra Basti procedure, to achieve the results in shorter duration, which was observed that patients were having symptomatical relief in subjective parameters assessed during $5^{\text {th }}$ day follow up.

Bahya and Abhyantara Snehana both at a time are necessary for Janusandhigata Vata as it is Vata Pradhana Doshaja Vyadhi commonly associated with the Vardhakya and Dhatu kshaya as a prominent feature in its manifestation. In this condition, Snehana plays a major role in mitigating Vata Dosha. Matrabasti with Saireyaka Taila helps in Dhatuposhana as it is Tikta Rasa Pradhana Draya processed with Ksheera helps in Asthi poshana as quoted in Charaka Samhita. Janu Basti with Saireyaka Taila does both Snehana and Svedana effects. The study has shown clinically and statistically very significant results in subjective and objective parameters when tested by paired T-test. Thus, the combined effect of Matrabasthi and Janubasti with Saireyaka Taila have shown very promising results in reversing the Samprapti of $\mathrm{Ja}$ nusandhigatavata.

\section{REFERENCES}

1. Agnivesha, Charaka Samhita, Ayurveda Deepika Commentary of Chakrapani Edited by Vaidya Yadav Ji Trikamji Acharya, Choukambha Krishnadas Academy Varanasi Year of Reprint-2015, Chikitsa Sthana Chapter-28 Verse-37, Pp738, Pg No-618

2. Sri Vaidya Shodala, Gada Nigraha, Vidyotini Hindi Commentary Edited by Sri Indradeva Tripathi, Gangashaya Pandeya, Choukambha Sanskrit Samsthana Year of Reprint- 2005 Kayachikitsa Khanda, Vatavyadhi Adhikara, Verse-166, Pp-571 Pg No. -509

3. Agnivesha, Charaka Samhita, Ayurveda Deepika Commentary of Chakrapani Edited by Vaidya Yadav Ji Trikamji Acharya, Choukambha Krishnadas Academy Varanasi Year of Reprint-2015, Chikitsa Sthana Chapter-28 Verse-75, Pp738, Pg No-620

4. Sushrutha, Sushrutha Samhitha, Nibandha Sangraha Commentary of Dalhanacharya and Nyayachandrika Panjika Commentary of Gayadasa, Edited by Acharya Priyavat Sharma, Choukambha Orientalia, Varanasi Year of Reprint -2014, Chikitsa Sthana, Chapter-4, Verse-8, Pp-824, Pg No-420

5. Sushrutha, Sushrutha Samhitha, Nibandha Sangraha Commentary of Dalhanacharya and Nyayachandrika Panjika Commentary of Gayadasa, Edited by Acharya Priyavat Sharma, Choukambha Orientalia, Varanasi Year of Reprint -2014, Chikitsa Sthana, Chapter-37, Verse-28, Pp-824, Pg No-261

6. Dr Gyanendra Pandey, Dravya Guna Vijnana, part 3 Choukambha Krishnadas Academy Varanasi Year of reprint -2014 Pp-1087 Pg No -283

7. Agnivesha, Charaka Samhita, Ayurveda Deepika Commentary of Chakrapani Edited by Vaidya Yadav Ji Trikamji Acharya, Choukambha Krishnadas 
Academy Varanasi Year of Reprint-2015, Siddhi Sthana Chapter-1 Verse-29, Pp738, Pg No-682

8. Vagbhata, Ashtanga Hridaya, Sarvanga Sundara of Arunadatta.Ayurveda Rasayana of Hemadri Commentary Edited by Pt. Hari Sadasiva Sastri Paradakara, Choukambha Sanskrit Sansthan Varanasi, Year of Reprint-2018, Sutra Sthana, Chapter- 16, Verse-3, Pp956 Pg No.- 243

9. Agnivesha, Charaka Samhita, Ayurveda Deepika Commentary of Chakrapani Edited by Vaidya Yadav Ji Trikamji Acharya, Choukambha Krishnadas Academy Varanasi Year of Reprint-2015, Sutra Sthana Chapter-28 Verse-27, Pp738, Pg No-180

\section{Source of Support: Nil \\ Conflict of Interest: None Declared}

How to cite this URL: Diksha Masimade et al: An Open Clinical Study To Assess The Combined Effect Of Janubast hi And Matra Basthi With Saireyaka Taila In Janusandhigatavata W.S.R.To Osteoarthritis Of Knee Joint. International Ayurvedic Medical Journal \{online\} 2021 \{cited November 2021\} Available from: http://www.iamj.in/posts/images/upload/2684_2691.pdf 